\title{
Pencemaran Tanah Oleh Pestisida di Perkebunan Sayur Kelurahan Eka Jaya Kecamatan Jambi Selatan Kota Jambi (Studi Keberadaan Jamur Makroza dan Cacing Tanah)
}

\author{
Supriatna, Sondang Siahaan*, Indah Restiaty \\ Politeknik Kesehatan Kemenkes Jambi \\ ${ }^{*}$ Correspondence email: shn.sondang@gmail.com
}

\begin{abstract}
Abstrak. Sayuran yang sehat hanya di dapat dari tanah pertanian yang sehat dan bebas pencemaran, termasuk pencemaran pestisida. Ketika suatu zat berbahaya atau beracun telah mencemari permukaan tanah, maka ia dapat menguap, tersapu air hujan dan atau masuk ke dalam tanah. Pencemaran yang masuk ke dalam tanah kemudian terendap sebagai zat kimia beracun di tanah. Zat beracun di tanah tersebut dapat berdampak langsung kepada manusia ketika bersentuhan atau dapat mencemari air tanah sehingga menurunkan fungsi tanah sebagai tempat tumbuh dan berkembangnya tanaman. Tujuan penelitian ini adalah ingin mengetahui gambaran pencemaran tanah oleh pestisida dan keberadaan cacing tanah serta jamur mikoriza dalam tanah. Penggunaan pestisida yang tidak sesuai dengan aturan dan formulasinya menyebabkan terjadinya pencemaran terhadap sayuran dan lingkungan seperti tanah dan air. Dengan mengambil sampel tanah dan melakukan pemeriksaan kandungan pestisida dapat diketahui apakah pestisida yang digunakan telah mencemari tanah. Keberadan cacing dan mikoriza akan semakin sedikit bahkan tidak ada sama sekali pada tanah yang telah tercemar. Hasil penelitian memperlihatkan, dari enam lokasi pengambilan sampel tanah ditemukan dua lokasi terjadi pencemaran pestisida karbamat $(33,3 \%)$, tidak ditemukan jamur mikoriza pada satu lokasi $(15,6 \%)$ dan cacing tanah ditemukan pada seluruh lokasi (100\%). Pencemaran terjadi karena petani sayur dan palawija menggunakan pestisida melebihi dosis yang dianjurkan dan terjadi pengulang dalam rentang waktu yang berdekatan. Jamur mikoriza banyak ditemukan dalam bentuk spora, spora jamur memiliki kemampuan bertahan yang lebih kuat di bandingkan batang utuh dari jamur mikoriza tersebut. Cacing tanah berasal dari pupuk kandang yang digunakan sebagai pupuk, selain kemampuanya menghindari tanah beracun keberadaan lendir pada tubuhnya dapat melindungi cacaing tabnah dari paparan pestisida.
\end{abstract}

Kata Kunci: Pestisida; Cacing Tanah; Jamur Mikoriza; Petani Sayur dan Palawija

Abstract. Healthy vegetables can only be from healthy and pollution-free farmland, including pesticide pollution. When a harmful or toxic substance has contaminated the surface of the soil, it can evaporate, be swept away by rainwater and or enter the soil. Pollution that enters the soil is then immersed as toxic chemicals in the soil. Toxic substances in the soil can have a direct impact on humans when touched or can contaminate groundwater thus lowering the function of the soil as a place of growing and developing plants. The purpose of this study is to find out the picture of soil pollution by pesticides and the presence of earthworms and mycoriza fungi in the soil. The use of pesticides that are not in accordance with the rules and formulations cause pollution to vegetables and the environment such as soil and water. By taking soil samples and checking the content of pesticides can be known whether the pesticides used have polluted the soil. The presence of worms and mycoriza will be less and less even none at all on the soil that has been polluted. The results showed that from six soil sampling locations found two locations of carbamate pesticide pollution (33.3\%), no mycoriza mushrooms were found at one location (15.6\%) and earthworms are found throughout the site (100\%). Pollution occurs because vegetable farmers and palawija use pesticides exceeding the recommended dose and occur pengulang in the adjacent time span. Mycoriza mushrooms are found in the form of spores, fungal spores have a stronger survival ability compared to the whole stem of the mycoriza fungus. Earthworms derived from manure used as fertilizer, in addition to its ability to avoid toxic soil mucus presence in his body can protect tabnah cacaing from pesticide exposure.

Keywords: Pesticides; Earthworms; Mycoriza mushrooms; Vegetable Farmer and Palawija

\section{PENDAHULUAN}

Makanan sehat seharusnya memiliki beragam kandungan nutrisi dalam jumlah yang memadai, termasuk mineral dan vitamin. Di antara jenis makanan, sayuran hijau adalah makanan sehat peringkat pertama karena memiliki kandungan nutrisi yang lengkap. Sayuran hijau tersebut, seperti sawi hijau, bayam, dan juga brokoli dengan kandungan serat yang tinggi. Sayuran yang sehat hanya di dapat dari tanah pertanian yang sehat dan bebas pencemaran, termasuk pencemaran pestisida.
Pencemaran tanah adalah keadaan di mana bahan kimia buatan manusia masuk dan merubah lingkungan tanah alami. Pencemaran ini biasanya terjadi karena: Polusi (Pencemaran) tanah biasanya terjadi karena kebocoran limbah cair, bahan kimia industry, atau fasilitas komersial, penggunaan pestisida, zat kimia, atau air limbah dari tempat penimbunan sampah serta limbah industri yang langsung dibuang ke tanah yang tidak memenuhi syarat/peraturan (illegal dumping).

Ketika suatu zat berbahaya atau beracun telah mencemari permukaan tanah, maka ia dapat menguap, tersapu air hujan dan atau masuk ke dalam tanah. 
Pencemaran yang masuk ke dalam tanah kemudian terendap sebagai zat kimia beracun di tanah.Zat beracun di tanah tersebut dapat berdampak langsung kepada manusia ketika bersentuhan atau dapat mencemari air tanah dan udara di atasnya.

Penggunaan pupuk anorganik, pestisida, dan insektisida seringkali membuat banyak organisme tanah seperti serangga dan hewan kecil tewas, dan hewan yang lebih besar yang memakan hewan kecil (seperti dalam rantai makanan) juga dirugikan. Pada akhirnya, residu dan sisa racun tersebut tercuci oleh hujan dan dari waktu ke waktu, mereka akan berakhir badan air dan menyebabkan pencemaran air. Pestisida yang ada di tanah dan air akan terserap melalui akar dan menetap dalam batang daun serta buah tanaman. Metabolisme kimia dari pestisida mempengaruhi kecepatan racun dan pencemar masuk dalam tanaman.

Pestisida sering kali menjadi andalan para petani dalam usaha mengamankan usaha tani kedelai dari hama maupun penyakit. Pestisida mempunyai beberapa kelebihan sehingga sering dimanfaatkan oleh petani, yaitu mudah diperoleh, cara aplikasi mudah serta hasil cepat tampak.

Pestisida mempunyai kekurangan berupa dampak buruk bagi kesehatan dan lingkungan. Residu pestisida bersifat karsinogenik (menyebabkan penyakit kanker) dan secara umum berdampak buruk bagi kesehatan. Residu pestisida dapat tertinggal dalam tanah dan air, menimbulkan resistensi hama dan penyakit serta musuh alami punah. Residu pestisida berdampak buruk bagi produk, manusia, dan lingkungan. Penggunaan pestisida tidak sepenuhnya mengenai sasaran sehingga menimbulkan residu dan berdampak negatif bagi tanah, air, tanaman maupun manusia. Perilaku petani yang kurang disiplin dalam penggunaan, baik dari segi jenis, takaran maupun frekuensi, dapat menyebabkan tingginya pencemaran.

Tanah pertanian yang tercemar dapat ditandai dengan menurunya kesuburan tanah, hal ini disebabkan karena beberapa hal antara lain hilangnya atau musnahnya sejenis cendawan yang disebut mikoriza. Beberapa mikroba tanah mampu menghasilkan hormon tanaman yang dapat merangsang pertum-buhan tanaman. Hormon yang dihasilkan oleh mikroba akan diserap oleh tanaman sehingga tanaman akan tumbuh lebih cepat atau lebih besar. Kelompok mikroba yang mampu menghasilkan hor-mon tanaman, antara lain: Pseudomonas sp dan Azotobacter sp.

Cendawan Mikoriza Arbuskula (CMA) adalah salah satu tipe cendawan pembentuk mikoriza yang akhir-akhir ini cukup populer mendapat perhatian dari para peneliti lingkungan dan biologis. Cendawan ini diperkirakan pada masa mendatang dapat dijadikan sebagai salah satu alternatif teknologi untuk membantu pertumbuhan, meningkatkan produktivitas dan kualitas tanaman terutama yang ditanam pada lahan-lahan marginal yang kurang subur atau bekas tambang/industri. Keberadan cendawan ini menjadi salah satu indikator tanah yang tercemar. Beberapa jenis cacing juga dapat hidup dalam tanah. Cacing selain sebagai hama juga berfungsi memberikan kesuburan pada tanah, melalui kotoran dan lubang udara yang dibuatnya sehingga tanah kaya akan oksigen.

Menurut Dinas Pertanian dan Ketahanan Pangan Kota Jambi, penggunaan pestisida kian hari kian bertambah. Dari sebanyak 3.500 liter menjadi 3.890 liter tidak termasuk di perkebunan sawit milik swasta. Luas lahan untuk pertanian di Kota Jambi cukup tersedia. Dari 3.432 ha lahan yang dapat digunakan untuk usaha pertanian, telah dimanfaatkan untuk pertanaman padi, palawija dan hortikultura seluas 2.404 ha (BPS Provinsi Jambi, 2004 : Bappeda Kota Jambi, 2006). Kawasan pertanian sayur dikota Jambi khususnya di Eka Jaya semakin lama semakin mengecil hal ini dikarenakan menurunya kesuburan tanah dan banyaknya lahan yang beralih fungsi menjadi permukiman. Penggunaan pestisida yang tidak terkendali dan penatalaksanaan tanah dianggap sebagai faktor penyebab pencemaran tanah dan terjadi penurun kesuburan tanah.

Data survei awal dari Kelurahan Eka Jaya diketahui bahwa saat ini terdapat lebih dari 200 orang petani sayur yang ada di kelurahan tersebut, namun hal ini mengalami penurunan karena jumlah lahan pertanian yang semakin mengecil juga dikarenakan sebagian besar lahan pertanian mengalami penurunan kesuburan tanahnya. Tidak seperti dulu, untuk menanam sayur seperti bayam tidak perlu menggunakan banyak pupuk kmia hanya pupuk kandang saja sudah menghasilkan sayuran yang subut dengan pertumbuhan yang pesat. Saat ini dibutuhkan waktu yang sedikit lama untuk mendapat kan sayuran yang baik selain itu perlu penembahan pupuk buatan agar hasilnya memuaskan. Menggunakan pestisida untuk menanggulangi beberapa penyakit yang ada pada tanaman secara tidak teratur berpotensi mencemari tanah dan mengurangi kesuburanya. Belum dilakukan penelitian mendalam tentang kandungan bahan kimia yang berasal dari pestisida yang ada dalam tanah. Salah satu zat kimia penyusun pestisida adalah chlor. Mengetahui jumlah chlor dalam tanah dapat dijadikan salah satu indikator pencemaran tanah.

Berdasarkan latar belakang tersebut peneliti tertarik untuk melakukan penelitian tentang Pencemaran Tanah oleh Pestisida dan keberadaan cacing serta mikoriza pada Petani sayur Kelurahan Eka Jaya Kecamatan Jambi Selatan Kota Jambi.

\section{METODE}

\section{Rancangan Penelitian}

Rancangan penelitian menggunakan rancangan penelitian diskriptif dengan pendekatan studi kasus. Studi kasus merupakan tipe pendekatan dalam penelitian yang penelaahanya kepada satu kasus dilakukan secara intensif, mendalam, mendetail, dan komprehensif. 
Karakteristik studi kasus adalah subjek yang diteliti sedikit tetapi aspek-aspek yang diteliti banyak.

\section{Desain Penelitian}

Kualitas penelitian dan ketepatan penelitian antara lain ditentukan oleh desian penelitian yang dipakai. Oleh karena itu desain yang dipergunakan dalam penelitian harus desain yang dapat dikatakan berkualitas atau memiliki ketepatan jika memenuhi dua syarat (Machfoedz, 2007), yaitu: 1) dapat dipakai untuk menguji hipotesis (khusus untuk penelitian kuantitatif analitik) dan 2) dapat mengendalikan atau mengontrol varians.

Secara garis besar desain penelitian ini termasuk non-ekperimental dimana tidak terjadi manipulasi terhadap variabel-variabel penelitian. Tujuan utama penggunaan desain non-eksperimen ialah bersifat eksplorasi dan deskriptif. Jika dilihat dari sisi tingkat pemahaman permasalahan yang diteliti, maka desain non-eksperimental menghasilkan tingkat pemahaman persoalan yang dikaji pada tataran permukaan.

\section{Model yang digunakan}

Model yang digunakan dalam penelitian ini adalah peneliti model deskriptip menjelaskan kondisi yang ada pada masa sekarang atau dapat disebut mendeskripsikan suatu gejala, peristiwa. Tujuan dilakukannya penelitian deskriptif antara lain (a) menjelaskan kondisi yang ada tanpa dipengaruhi oleh peneliti dan lainya dan, kemudian dapat dilakukan berbagai modifikasi, dan (b) merupakan upaya untuk pemecahan masalah praktis pendidikan (sedikit sekali untuk fungsi pengembangan ilmu).Karakteristik penelitian deskriptif :1.Peneliti memotret peristiwa yang menjadi pusat perhatian untuk kemudian digambarkan sebagaimana adanya.2.Permasalahan penelitian adalah permasalahan yang terjadi pada saat penelitian dilaksanakan sehingga manfaat temuan berlaku pada saat itu.3.Penelitian deskriptif tidak selalu menuntut adanya hipotesis, tidak memperlakukan manipulasi variabel. 4.Variabel yang diteliti bisa tunggal, bisa lebih dari satu, bahkan bisa mendeskripsikan hubungan antar variabel.

\section{Perubahan Yang Diamati}

Perubahan yang diamat adalah tentang kesuburan tanah yang merupakan salah satu ciri terjadinta pencemaran tanah. Tanah yang telah tercemar akan menurun kemampuanya dalam menyuburkan tanaman yang tumbuh diatasnya. Kemampuan ini dikarenakan ikatan oksigen dan nistrogen oleh mikroorganisme dalam tanah sudah hilang sehingga tanah menjadi tidak subur.

\section{Lokasi Penelitian}

Penelitian dilakukan di perkebunan sayur keluarahan Eka Jaya Kota Jambi.

\section{Jumlah Sampel dan Teknik Pemeriksan Sampel}

Jumlah sampel tanah yang diambil adalah sebanyak 6 buah dengan teknik pemeriksaan di laboratorium tanah Balitbang Pertanian dan Perkebunan Kota Jambi.

\section{Teknik Pengumpulan Data dan Analisis Data Jamur Mikoriza}

Sampel yang digunakan diambil dari tanah yang tercemar secara komposit pada kedalaman 0-20 cm. Faktor lingkungan yang diamati antara lain adalah $\mathrm{pH}$ tanah, suhu tanah, kelembapan tanah dan intensitas cahaya. Isolasi jamur mikoriza dilakukan dengan teknik mengekstrak spora dengan cara tuangsaring berdasarkan metode Pacioni (1992) dalam Yassir dan Mulyana (2006), yakni dengan mencampurkan tanah sampel sebanyak $50 \mathrm{~g}$ dengan $500 \mathrm{ml}$ air dan diaduk sampai butiranbutiran tanah tersuspensi, kemudian disaring dalam satu set saringan dengan nomor mesh 10, 20, 40, $60,80,100$. Tanah yang diambil adalah tanah yang ada pada saringan 20 dan 40 . Teknik tuang saring tersebut kemudian dilanjutkan dengan teknik sentrifugasi berdasarkan metode Brundrett et al (1996) dalam Yassir dan Mulyana (2006) dan hasil saringan kemudian ditambahkan aquades sampai $30 \mathrm{ml}$ kemudian di sentrifugasi dengan kecepatan 2000 rpm selama 5 menit.

Diambil pelet kemudian ditambahkan sukrosa 80\% sebanyak $15 \mathrm{ml}$, kemudian disentrifugasi kembali dengan kecepatan 2000 rpm selama 1 menit. Supernatan dimasukkan ke dalam cawan petri kemudian diamati dengan menggunakan mikroskop. Pemeriksaan dilakukan di Laboratorium Tanah Balitbang Pertanian dan perkebunan Kota Jambi.

\section{Cacing Tanah}

Pada titik pengambilan sampel dilakukan pembuatan petakan sebesar 1 (satu) meter persegi, kemudian dilakukan penggalian sedalam $20 \mathrm{~cm}$ untuk memperoleh keberadaan cacing dewasa yang dapat diamati langsung dengan mata. Dan selanjutnya dilakukan pengambilan sampel tanah untuk mengetahui keberadaan cacing dalam tanah. Pemeriksaan dilakukan di Laboratorium Balitbang Pertanian dan Perkebunan Kota Jambi.

\section{Analisa data}

Univariat bertujuan untuk mendapatkan gambaran dalam bentuk tabel distribusi frekuensi masing-masing variable yang diteliti baik variable independen maupun variable dependen.

\section{HASIL DAN PEMBAHASAN}

Penelitian ini dilakukan pada musim kemarau dan memasuk musim hujan dengan intensitas hujan yang turun tidak setiap hari. Salah satu kendala dalam penelitian ini adalah sulitnya mencari lokasi penelitian karena tidak semua lahan pertanian dapat selalu 
ditanamami sayuran. Selain mengandalkan dari air hujan petani juga menggunakan air dari sumur maupun kolamkolam yang ada di sekitar lahan pertanian.

Pada musim kemarau seperti tahun ini tidak semua kolam dan sumur masih menyimpan air, sebahagian sumur dan kolam telah mengering. Penelitian ini juga tidak dapat dilakukan selama lahan pertanian belum ditanamai sayuran, karena bila tidak ada sayuran maka aplikasi pestisida tidak dapat dijalankan atau penyemprotan pestisida tidak dapat dilakukan.

\section{Pencemaran tanah oleh pestisida pada petani sayur Kelurahan Eka Jaya Kota Jambi}

Aplikasi pestisida yang digunakan tergantung dari keperluan dan jenis hama penyakit yang menyerang tanaman sayur. Pada saat penelitian Pestisida yang digunakan jenis Furadan 3G dan Dithane dengan bahan aktif karbofuran. Namun pada waktu yang lalu atau pada saat persipan tanah sebelum dilakukan penyemaian bibit biasanya tanah di semprot pestisida sebagai bagian dari persipan lahan.

Menjelaskan kepada petani maksud dan tujuan penelitian dan berusaha tidak mengganggu kegiatan pertanian yang sedang berjalan maka peneliti mulai melakukan pemetaan dan penentuan titik pengambilan sampel tanah. Sampel tanah diambil dan dikirimkan ke laboratorium untuk dianalisis. Setelah dilakukan pemeriksaan terhadap sampel tanah maka diketahui bahwa beberapa lokasi memiliki kandungan pestisida dalam tanahnya. Untuk lebih lengkapnya dapat dilihat sebagai berikut :

Tabel 1. Kandungan Pestisida di Tanah pada Petani Sayur Kelurahan Eka Jaya Kota Jambi

\begin{tabular}{llccc}
\hline No & Lokasi & \multicolumn{3}{c}{ Kandungan Pestisida } \\
\cline { 3 - 5 } & Sampel & Organophospat & Karbamat & Organochlorin \\
\hline 1 & A & Negatif & Negatif & Negatif \\
2 & B & Negatif & Positif & Negatif \\
3 & C & Negatif & Negatif & Negatif \\
4 & D & Negatif & Negatif & Negatif \\
5 & E & Negatif & Positif & Negatif \\
6 & F & Negatif & Negatif & Negatif \\
\hline
\end{tabular}

Berdasarkan hasil pemeriksaan laboratorium terhadap tanah pada enam lokasi, dapat dilihat bahwa lokasi sampel kebun A dan E masih ditemukan pestisida dalam tanahbun.

\section{Keberadaan Jamur mikoriza sebagai indikator pencemaran tanah oleh pestisida pada petani sayur Kelurahan Eka Jaya Kota Jambi}

Beberapa jenis jamur menjadi hama pada tanaman, tidak halnya dengan jamur Mikoriza yang memiliki manfaat yang besar bagi pertumbuhan tanaman. Keberadaanya sangat diharapkan, namun dapat lenyap dan mati karena perlakuan buruk terhadap tanah dan beberapa kondisi fisik lingkungan yang tidak menguntungkan termasuk cemaran pestisida ada tanah.
Mikoriza dapat diamati menggunakan mikroskop dalam bentuk bagian yang utuh maupun dalam bentuk spora. Melalui perlakuan khusus di laboratorium, keberadaanya dalam tanah dapat diketahui sebagai berikut :

Tabel 2. Keberadaan Jamur Mikoriza di Tanah pada Petani Sayur Kelurahan Eka Jaya Kota Jambi

\begin{tabular}{ccccc}
\hline No & Lokasi & \multicolumn{2}{c}{ Keberadaan Jamur } & Keterangan \\
\cline { 3 - 4 } & Sampel & Ada & Tidak Ada & \\
\hline 1 & A & V & - & Spora \\
2 & B & - & V & - \\
3 & C & V & - & Utuh \\
4 & D & V & - & Spora \\
5 & E & V & - & Spora \\
6 & F & V & - & Utuh \\
\hline
\end{tabular}

Berdasarkan tabel diatas jamur mikoriza masih dapat ditemukan di semua lokasi kecuali pada lokasi B. Mikoriza dalam bentuk spora lebih memiliki daya tahan dibanding pada saat dia dewasa.

Keberadaan cacing tanah sebagai indikator pencemaran tanah oleh pestisida pada petani sayur Kelurahan Eka Jaya Kota Jambi

Bebarapa jenis cacing mudah ditemukan pada tanah-tanah yang subur dan mengandung banyak zat organik sperti lahan pertanian. Beberapa jenis cacing yang ditemukan antara lain jenis Megascolex, Pontoscolex dan Pheretima. Keberadaan cacing dihitung berdasarkan kepadatanya, semakin padat cacing maka semakin subur lahan pertanian tersebut dan terbebas dari pencemaran pestisida. Berikut ini adalah cacing jenis Megascolex dan nilai kepadatanya pada lokasi penelitian:

Tabel 3. Keberadaan Cacing di Tanah pada Petani Sayur Kelurahan Eka Jaya Kota Jambi

\begin{tabular}{ccccc}
\hline No & $\begin{array}{c}\text { Lokasi } \\
\text { Sampel }\end{array}$ & \multicolumn{2}{c}{ Keberadaan Cacing } & \multirow{2}{*}{$\begin{array}{c}\text { Kepadatan } \\
\text { Cacing }\end{array}$} \\
\cline { 3 - 4 } & A & V & Tidak Ada & 0,755 \\
2 & B & V & - & 0,167 \\
3 & C & V & - & 0,687 \\
4 & D & V & - & 0,771 \\
5 & E & V & - & 0,247 \\
6 & F & V & - & 0,656 \\
\hline
\end{tabular}

Selain keberadaan hal penting lain dari cacing adalah kepadatanya. Kepadatan cacing ditentukan dengan satuan lebih besar atau lebih kecil dari 1. Apabila mendekatil maka populasi cacaing sangat padat. Berdasarkan hal tersebut maka kepadatan cacing tertinggi berada di lokasi sampel D sedangkan kepadatan terendah berada pada sampel B. 


\section{Pembahasan}

Secara umum tidak terjadi pencemaran tanah oleh pestisida pada petani sayur Kelurahan Eka Jaya Kecamatan Jambi Selatan Kota Jambi

Penyemprotan adalah cara penggunaan pestisida yang paling banyak dipakai oleh petani. Diperkirakan 75 $\%$ penggunaan pestisida dilakukan dengan cara penyemprotan. Dalam penyemprotan larutan pestisida (pestisida diatambah air) dipecah oleh nozzel (spuyer) atau atomizer menjadi butiran semprot atau droplet. Bentuk sediaan (formulasi) yang digunakan dengan cara penyemprotan meliputi E.C; W.P; WS atau SP. Sedangkan penyemprotan dengan volume ultra rendah (Ultra low volume) digunakan formulasi ULV. Dengan menggunakan alat khusus yang disebut mikroner.

Gambaran yang di peroleh dari pencemaran tanah yaitu keadaan dimana bahan kimia buatan manusia masuk dan merubah lingkungan tanah alami. Pencemaran tanah dapat terjadi karena penggunaan pestisida berlebihan. Penggunaan pestisida yang berlebihan akan mengakibatkan $\mathrm{pH}$ tanah turun, tanah menjadi asam hingga kesuburannya menurun, selain itu, kandungan pestisida yang beracun akan mengendap di tanah dan berbahaya jika terjadi kontaminasi dengan manusia.

Pencemaran tanah yang terjadi di daerah penelitian tergolong ringan, hal ini dibuktikan dengan $\mathrm{pH}$ tanah yang tidak terlalu asam (berkisar 5,5-6,2) dan keadaan tanah yang tidak terlalu kering. Keadaan lingkungan di sekitar objek penelitian dilaporkan tidak pernah terjadi penyakit kulit atau penyakit lain yang memungkinkan terjadi akibat penggunaan pestisida. Luas tanah daerah penelitian tidak terlalu luas sehingga penggunaan pestisida tidak dalam skala besar.

Pemakaian pupuk dan pestisida dalam jumlah yang besar menimbulkan pencemaran bagi tanah dan air tanah dengan kadar racun yang beraneka ragam.

Ada beberapa pengaruh negatif lainnya pemakaian pestisida sintetis secara tidak sesuai, yaitu: 1). Pencemaran air dan tanah yang pada akhirnya akan berpengaruh terhadap manusia dan makhluk lainnya dalam bentuk makanan dan minuman yang tercemar; 2). Matinya musuh alami dari hama maupun patogen dan akan menimbulkan resurgensi, yaitu serangan hama yang jauh lebih berat dari sebelumnya; 3). Kemungkinan terjadinya serangan hama sekunder. Contohnya: penyemprotan insektisida sintetis secara rutin untuk mengendalikan ulat grayak (hama primer) dapat membunuh serangga lain seperti walang sembah yang merupakan predator kutu daun (hama sekunder). Akibatnya setelah ulat grayak dapat dikendalikan, kemungkinan besar tanaman akan diserang oleh kutu daun; 4). Kematian serangga berguna dan menguntungkan seperti lebah yang sangat serbaguna untuk penyerbukan; 5). Timbulnya kekebalan/resistensi hama maupun patogen terhadap pestisida sintetis; 6).
Kesuburan tanah di lahan-lahan yang menggunakan pestisida dari tahun ke tahun menurun.

Berdasarkan hasil penelitian diketahui bahwa terdapat dua lokasi yang masih terdeteksi adanya pencemaran pestisida. Penggunaan estisida merupakan jalan terakhir bila penanggulangan secara meknik dan fisik tidak dapat dilaksanakan. Kedua likasi merupakan lahan yang terserang ulat daun dan belalang, bila dibiarkan akan terjadi kegagalan panen. Penyemprotan dilakukan minimal 10 (sepuluh) hari sebelum pemanenan. Sayur bayam memiliki umur tanam sekitar 30 hari sehingga batas penyemprotan dapat dilakukan maksimal pada umur sayur bayam 20 hari. Penyemprotan dilakukan pada awal musim hujan sehingga prediksi datangnya hujan sulit dilakukan. Terjadi pencucian tanah oleh air hujan mengakibatkan pestisida tidak ditemukan lagi di dalam tanah.

Apabila tanah sudah terlanjur dicemari oleh pestisida, maka cara memperbaikinya adalah dengan cara remediasi. Remediasi adalah kegiatan untuk membersihkan permukaan tanah yang tercemar. Ada dua jenis remediasi tanah, yaitu in situ (atau on-site) dan exsitu (atau off-site). Pembersihan on-site adalah pembersihan di lokasi. Pembersihan ini lebih murah dan lebih mudah, terdiri dari pembersihan venting (injeksi).

Pembersihan off-site meliputi penggalian tanah yang tercemar dan kemudian dibawa ke daerah yang aman. Setelah itu di daerah aman, tanah tersebut dibersihkan dari zat pencemar. Caranya yaitu, tanah tersebut disimpan di bak/tanki yang kedap, kemudian zat pembersih dipompakan ke bak/tangki tersebut. Selanjutnya zat pencemar dipompakan keluar dari bak yang kemudian diolah dengan instalasi pengolah air limbah. Pembersihan off-site ini jauh lebih mahal dan rumit.

Bioremediasi adalah proses pembersihan
pencemaran tanah dengan menggunakan mikroorganisme (jamur, bakteri). Bioremediasi bertujuan untuk memecah atau mendegradasi zat pencemar menjadi bahan yang kurang beracun atau tidak beracun (karbon dioksida dan air).

Bioremediasi adalah proses pembersihan
pencemaran tanah dengan menggunakan
mikroorganisme (jamur, bakteri). Bioremediasi adalah penggunaan mikriirganisme untuk menurangi polutan di lingkungan. Bioremediasi adalah proses penguraian limbah organik atau anorganik polutan.

Untuk pencemaran tanah akibat pestisida di Kelurahan Eka Jaya dapat diatasi dengan sosialisasi mengenai penggunaan pestisida sesuai dosis yang baik dan benar kepada para petani, hal ini karena pencemaran yang terjadi tidak dalam skala besar/terlalu berat yang memerlukan solusi bioremediasi/remediasi. 
Masih terdapat Jamur mikoriza sebagai indikator pencemaran tanah oleh pestisida pada petani sayur Kelurahan Eka Jaya Kecamatan Jambi Selatan Kota Jambi

Tanaman yang bermikoriza tumbuh lebih baik dari tanaman tanpa bermikoriza. Penyebab utama adalah mikoriza secara efektif dapat meningkatkan penyerapan unsur hara baik unsur hara makro maupun mikro. Selain daripada itu akar yang bermikoriza dapat menyerap unsur hara dalam bentuk terikat dan yang tidak tersedia bagi tanaman (Anas, 1997).

Selain daripada membentuk hifa internal, mikoriza juga membentuk hifa ekternal. Pada hifa ekternal akan terbentuk spora, yang merupakan bagian penting bagi mikoriza yang berada diluar akar. Fungsi utama dari hifa ini adalah untuk menyerap fospor dalam tanah. Fospor yang telah diserap oleh hifa ekternal, akan segera dirubah manjadi senyawa polifosfat. Senyawa polifosfat ini kemudian dipindahkan ke dalam hifa internal dan arbuskul. Di dalam arbuskul. Senyawa polifosfat ini kemudian dipindahkan ke dalam hifa internal dan arbuskul. Di dalam arbuskul senyawa polifosfat dipecah menjadi posfat organik yang kemudian dilepaskan ke sel tanaman inang.

Adanya hifa ekternal ini penyerapan hara terutama posfor menjadi besar dibanding dengan tanaman yang tidak terinfeksi dengan mikoriza. Peningkatan serafan posfor juga disebabkan oleh makin meluasnya daerah penyerapan, dan kemampuan untuk mengeluarkan suatu enzim yang diserap oleh tanaman. Sebagai contoh dapat dilihat pengaruh mikoriza terhadap pertumbuhan berbagai jenis tanaman dan juga kandungan posfor tanaman (Anas, 1997).

Beberapa keuntungan yang diperoleh dengan adanya simbiosis ini adalah: 1) miselium fungi meningkatkan area permukaan akuisisi hara tanah oleh tanaman; 2) meningkatkan toleransi terhadap kontaminasi logam, kekeringan, serta patogen akar; 3) memberikan akses bagi tanaman untuk dapat memanfaatkan hara yang tidak tersedia menjadi tersedia bagi tanaman (Gentili \& Jumpponen, 2006).

Selanjutnya Sagin Junior dan Da Silva dalam Novriani dan Madjid (2009) mengungkapkan bahwa adanya mikoriza berpengaruh terhadap: 1) adanya peningkatan absorpsi hara, sehingga waktu yang diperlukan untuk mencapai akar lebih cepat; 2) meningkatkan toleransi terhadap erosi, pemadatan, keasaman, salinitas, 3) melindungi dari herbisida, serta; 4) memperbaiki agregasi partikel tanah.

Selain itu manfaat dari adanya Mikoriza adalah : 1). Peningkatan Ketahanan terhadap Kekeringan kareana akar yang mengandung mikoriza mampu menyimpan air; 2). Lebih Tahan terhadap Serangan Patogen Akar Mikoriza dapat meningkatkan pertumbuhan tanaman melalui perlindungan tanaman dari patogen akar dan unsur toksik. Juga dapat berfungsi sebagai pelindung biologi bagi terjadinya patogen akar. Terbungkusnya permukaan akar oleh mikoriza menyebabkan akar terhindar dari serangan hama dan penyakit. Infeksi patogen akar terhambat. Tambahan lagi mikoriza menggunakan semua kelebihan karbohidrat dan eksudat akar lainnya, sehingga tercipta lingkungan yang tidak cocok bagi pathogen; 3). Produksi Hormon dan zat Pengatur Tumbuh seperti, sitokinin dan giberalin. Cendawan mikoriza bisa membentuk hormon seperti auxin, citokinin, dan giberalin, yang berfungsi sebagai perangsang pertumbuhan tanaman; 4). Manfaat Tambahan dari Mikoriza

Penggunaan inokulum yang tepat dapat menggantikan sebagian kebutuhan pupuk. Sebagai contoh mikoriza dapat menggantikan kira-kira 50\% kebutuhan fosfor, $40 \%$ kebutuhan nitrogen, dan $25 \%$ kebutuhan kalium untuk tanaman lamtoro (De la cruz, 1981 dalam Husin dan Marlis, 2002); 5). Perbaikan Struktur Tanah.Cendawan mikoriza melalui jaringan hifa eksternal dapat memperbaiki dan memantapkan struktur tanah. Sekresi senyawa-senyawa polisakarida, asam organik dan lendir oleh jaringan hifa eksternal yang mampu mengikat butir-butir primer menjadi agregat mikro. "Organic binding agent" ini sangat penting artinya dalam stabilisasi agregat mikro. Kemudian agregat mikro melalui proses "mechanical binding action" oleh hifa eksternal akan membentuk agregat makro yang mantap.

Pembentukan struktur tanah yang baik merupakan modal bagi perbaikan sifat fisik tanah yang lain. Sifatsifat fisik tanah yang diperbaiki akibat terbentuknya struktur tanah yang baik seperti perbaikan porositas tanah, perbaikan permeabilitas tanah serta perbaikan dari pada tata udara tanah.

Perbaikan dari struktur tanah juga akan berpengaruh langsung terhadap perkembangan akar tanaman. Pada lahan kering dengan makin baiknya perkembangan akar tanaman, akan lebih mempermudah tanaman untuk mendapatkan unsur hara dan air, karena memang pada lahan kering faktor pembatas utama dalam peningkatan produktivitasnya adalah kahat unsur hara dan kekurangan air. Akibat lain dari kurangnya ketersediaan air pada lahan kering adalah kurang atau miskin bahan organik. Kemiskinan bahan organik akan memburukkan struktur tanah, lebih-lebih pada tanah yang bertekstur kasar sehubungan dengan taraf pelapukan rendah;.6). Meningkatkan Serapan Hara P.

\section{Masih ditemui keberadaan cacing tanah sebagai indikator pencemaran tanah oleh pestisida pada petani sayur Kelurahan Eka Jaya Kota Jambi}

Keanekaragaman jenis cacing yang tinggi dipengruhi oleh rona lingkungan.Selain itu juga dipengaruhi oleh air lindi yang merupakan cairan hasil dari dekomposisi pupuk kandang yang banyak mengandung berbagai zat organik dan anorganik. Lindi yang telah terdekomposisi dengan baik akan meningkatkan kadar kimia tanah seperti KOT, C- 
organik, N-total dan $\mathrm{pH}$ akan berpengaruh keanekaragaman jenis cacing tanah pertanian Kelurahan Eka Jaya Kota Jambi.

Keanekaragaman jenis dan kepadatan lebih tinggi berada di lokasi $\mathrm{D}$ dibandingkan dengan lokasi lain disebabkan kondisi habitat yang beragam yang terdiri dari tanaman bayam, rumput dan beberapa tumbuhan herba lainnya. Suin (2003) menyatakan bahwa keanekaragaman jenis cenderung lebih tinggi pada daerah dengan kondisi habitat yang beragam.

Kemerataan tertinggi terlihat pada Lokasi D $(\mathrm{E}=0,771)$, karena kemerataan kepadatan jenis antara Megascolex, Pontoscolex dan Pheretima ditemukan lebih seimbang jika dibandingkan pada lokasi lainnya yang populasinya sangat didominasi oleh Megascolex. Nilai dominansi cacing tanah berdasarkan indeks Simpson pada keenam lokasi tergolong tinggi yaitu berkisar antara 0,771-0,167. Odum (1993) menyatakan bahwa jika nilai dominansi mendekati 1 , maka pada komunitas tersebut ada jenis yang mendominasi dan dalam keadaan labil akibat tekanan ekologis yang tinggi. Hal ini sesuai dengan kondisi stasiun I yang mempunyai nilai dominansi mendekati $1(\mathrm{D}=0,771)$.

Tingginya nilai dominansi jenis tersebut terlihat dari jumlah populasi Megascolex yang sangat besar dibandingkan genera lainnya. Megascolex lebih tahan terhadap limpasan air yang banyak mengandung bahan organik. Selain itu, perbedaaan kondisi vegetasi antar tiap stasiun juga berpengaruh terhadap keberadaan Megascolex. Megascolex menyukai tanah yang memiliki tumbuhan dengan perakaran bertekstur lembut seperti tanaman pisang yang banyak ditemukan pada stasiun I.

\section{SIMPULAN}

Pencemaran tanah oleh pestisida pada petani sayur Kelurahan Eka Jaya Kota Jambi terjadi pada lokasi B dan E.

1. Masih terdapat Jamur mikoriza sebagai indikator tidak terjadi pencemaran tanah oleh pestisida pada petani sayur Kelurahan Eka Jaya Kota Jambi kecuali lokasi B.

2. Masih ditemui keberadaan cacing tanah sebagai indikator tidak terjadi pencemaran tanah oleh pestisida pada petani sayur Kelurahan Eka Jaya Kota Jambi namun kepadatan terendah pada lokasi $\mathrm{E}$

\section{DAFTAR PUSTAKA}

Anas, I. 1997.Bioteknologi Tanah. Laboratorium Biologi Tanah. Jurusan Tanah. Fakultas Pertanian. IPB

BPS Provinsi Jambi, 2004

Bappeda Kota Jambi, 2006

Gentili, F and A. Jumpponen. 2006. Potential and Possible Uses of Bacterial and Fungal Biofertilizers. In: Handbook of Microbial Biofertilizers. Hawort Press, Technology and Enginering, New York, pp 1- 28.
Husin, E. F. dan Marlis, R. 2002. Aplikasi Cendawan Mikoriza Arbuskular sebagai pupuk biologi pada pembibitan kelapa sawit. Prosiding Seminar Nasional BKS PTN Wilayah Indonesia Barat, FP USU Medan.

Machfoedz.I. 2007. Metodologi Penelitian Bidang Kesehatan, Keperawatan, dan Kebidanan. Yogyakarta: Fitramaya

Novriani dan Madjid. 2009. Peran dan Prospek Mikoriza.

http://phosphateindo.com/article/13157/perandan-prospekmikoriza.html.

Odum, E. P. 1993.Dasar-dasar Ekologi. Terjemahan Tjahjono Samingan. Edisi Ketiga. Gadjah Mada University Press. Yogyakarta.

Suin, N.M.2003. Ekologi Hewan Tanah.Bumi Aksara dan Pusat Antar Universitas Ilmu Hayati.ITB.

Yassir I dan Mulyana O. 2006. Hubungan Potensi Antara Cendawan Mikoriza Arbuskular dan Sifatsifat Tanah Di Tanah Kritis. Jurnal Penelitian Hutan Tanaman, 3 (2): 107-115 